\title{
STUDENTS' CREATIVITY IN GEOMETRY COURSE : HOW A MYSTERY BOX GAME PLAYS IMPORTANT ROLE
}

\author{
Wanda Nugroho Yanuarto \\ Universitas Muhammadiyah Purwokerto \\ wandanugroho86@gmail.com
}

\begin{abstract}
The purpose of this study are encouraging students' creativity by mystery box games and become more aware of their mathematical thinking. The situational problem as the starting point helps students to relate what they learn to problems in daily life, and construct and interpret geometry that are related to real situations, and this helps to correct their alternative conceptions in geometry courseto encourage students' creativity in Geometry Course. There are three abilities to encouraging students'creativity, they are synthetic ability, analytic ability, and practical ability. The subjects of this research is the students of the $1^{\text {st }}$ semester of 2014 academic year class A of mathematical education of Muhammadiyah University of Purwokerto, Central Java, Indonesia. The data of this research is through observation sheet, recording videos, portofolios, and questionnaires. Those data was analyzed through data reduction, data presentation, and conclusion. This study shows that to encouraging students' creativity can analyzed by mystery box in Geometry Course.
\end{abstract}

Keywords: Students' creativity, geometry course, mystery box

Abstrak. Tujuan dari penelitian ini adalah mendorong kreativitas mahasiswa dengan permainan mystery box dan menumbuhkan kesadaran akan berpikir matematis mahasiswa. Masalah situasional sebagai titik awal dalam penelitian ini adalah mengaitkan apa yang mereka pelajari dalam konsep matematis kedalam kehidupan sehari-hari, dan membangun serta menafsirkan geometri yang terkait dengan situasi nyata. Hal ini akan membantu mahasiswa memperbaiki konseps matematis tentang geometri dan mendorong kreativitas. Ada tiga kemampuan untuk mendorong kreativitas siswa, yaitu: kemampuan sintetis, kemampuan analitik, dan kemampuan praktis. Subyek penelitian ini adalah mahasiswa semester 1 Tahun Akademik 2014/2015 kelas A pendidikan matematika Universitas Muhammadiyah Purwokerto, Jawa Tengah, Indonesia. Data dari penelitian ini adalah melalui lembar observasi, rekaman video, portofolio, dan kuesioner. Data tersebut dianalisis melalui reduksi data, penyajian data, dan kesimpulan. Studi ini menunjukkan bahwa untuk mendorong kreativitas mahasiswa dapat dianalisis dengan permainan mystery box pada mata kuliah geometri.

Kata kunci: Kreativitas Mahasiswa, mata kuliah geometry, mystery box

\section{Introduction}

Mathematics is one of the areas of study that taught at every level of education. Many issues and problems in life that must be solved using mathematical sciences such as counting, measuring, and others. Therefore, mathematics as one of the basic of science has an important role in educating students because it can foster reasoning skills that needed in the developing science and 
technology. Study of mathematics is divided into several areas, including geometry. The role of geometry in mathematics is very clear, not just guiding the process of thinking but also greatly affect other areas of mathematics. The resolve the problem in geometry, the student must understand the concept first or the properties of the geometry so it is will be easy to understand and solve the problem which is happened in geometry. By looking at those situations, there are many ways to improve the quality of mathematics education. Lecturer or lecturer must teach and learn the activity in class effectively and efficiently (Haylock, 2011; Fleith, 2010; Ross, 2012). That's why they have a strategy to allow students reach their knowledge, being master the concepts and rules of the material and be able to connect material into real life situation.In this case, especially for new students of Mathematic Subject in University of Muhammadiyah Purwokerto. Lecturer have to introduced how learning in class look like, how to participated their ability in mathematics and how to encourage creativity of students. By those situations, hopefully students can communicate their opinions, ideas, and creating their thinking during the class. So at this time the activities of lesson study authors assume that how teaching and learning process innovated through the game and encourage students creativity (Jensen, 2009; Hennessdy, 2008; Sloan, 1996).

Creativity requires a balance among synthetic, analytic, and practical abilities. The person who is only synthetic may come up with innovative ideas, but cannot recognize or sell them. The person who is only analytic may be an excellent critic of other people's ideas, but is not likely to generate creative ideas. The person who is only practical may be an excellent salesperson, but is as likely to sell ideas or products of little or no value as to sell genuinely creative ideas. The National council of Lecturers of Mathematics Task force on the Mathematically Promising (Sheffield et.al., 1995) characterized our promising young mathematics students in light of their ability, motivation, belief, and opportunity, all considered variables that must be maximized to fully develop a student's mathematical talent. Davis (1969) considered developing creativity in students of mathematics in terms of three major parameters: attitudes, abilities, and techniques (methods of preparing and manipulating information). While 26 years separate these efforts, they offer similar recommendations. In searching for potentially creative student mathematicians, using existing creativity instruments is difficult to do for entire grade levels due to the tie involved in scoring such instruments. Yet, relying solely on lecturer recommendations provides an incomplete picture of the students (Hashimoto, 1997 ; Kohler, 1997).

In the present, geometry accupies a special position in mathematics curriculum because a lot of concepts contained there in. from the psychological point of view, the geometry consist of representation in visual and spatial experience, e.g field, pattern, measurement, and mapping. Meanwhile, from the standpoint of mathematics, geometry provides approaches to solve that kind of problems such as images, diagrams, coordinate systems, and vectors. From those situations, it can be concluded that in Analytical Geometry course that teach and learn in class a of $1^{\text {st }}$ semester is presented significant learning that students can make the schema concept in their minds, need good process of learning by using game so that process can be fun, memorable, and helpful, the game here is Mystery Box.

Regarding the background, the authors expected the following to occur during the teaching and learning activities: a) Concerning the Mystery Box: Students will encourage their creativity and become more aware of their mathematical thinking. The situational problem as the starting point helps students to relate what they learn to problems in daily life. The class environment becomes livelier. The lecturer might have difficulty in the beginning to adjust to his new role in the activities; 
e.g., he might have problems with guiding the class discussion because this is new to him; and b) Concerning the Mystery Box: It enables students themselves to construct and interpret geometry that are related to real situations, and this helps to correct their alternative conceptions in geometry course. The class set-up encourages students to become engaged and to be more creative in the work. There might be technical problems related to the Geometry course environment or to the lecturer's capability to master it in a short time.

\section{Research Method}

By those theories the authors can concludethe method how to help students to learn a geometry concept, they are: 1) Show students both correct and incorrect examples of the geometric concept. Show the concept in different ways or representations. Ask the students to distinguish between correct and incorrect examples. This will help prevent misconceptions. 2) Ask students to draw correct and incorrect examples themselves. 3) Trying in with the previous point, ask the students to provide a definition for a concept. This gets them to thinking about which properties in the definition are necessary and which are not. 4) Allow the students to experiment, investigate, and play with geometrical ideas and figures. Use manipulatives, drawing, and apps or software (more on them below). 5) Have students make their own geometry notebook, filled with examples, nonexamples, definitions, and other notes and drawings.

This research is a qualitative descriptive study based learning stages of lesson study. The study was conducted in the first semester of the academic year of 2014/2015 at the University of Muhammadiyah Purwokerto (UMP). The subjects of this study is the first semester students of class A UMP Mathematics Education that cover in Analytic Geometry Course of odd semester academic year of 2014/2015.
On the other hand, what happens in the mystery box? That questions can be answered by the following step: 1) Make one problem which related by material on learning today; 2) Problem is made in the paper available; 3) Make the key answer of the question on a separate sheet of paper about; 4) The answer key is made in the other paper; 5) Time to answer the questions are 10 minutes; 6) Once the matter is made, then put in a box that has been provided; 7) Each box is available with a different value with the auction system; 8) Then the box is opened and do on the problems that exist in it. If the matter is done right, then the value which obtained in accordance with the existing value in each box; and 9)Conversely, if the matter can not be done obtained or done incorrectly, then the group will be reduced in accordance with the value of the value in the box

\section{Result and discussion}

Many various ways that can do by the lecturers to make classroom learning process more interesting for students, so the authors make a strategy in its class by Mystery Box Games. It is created by team building combines board games and card games. Mystery Box can be done by groups with each group was given the responsibility to carry out the game together. Form of the games is using the box which there is a score inside. The score can be achieved by the group that can solve the problem, otherwise if it can not resolve the problem, then the group will get a penalty in the form of a reduction in the existing score in the box. Each group is obliged to make a problem and solve it. Then the problem written on paper and put in a box that has been provided. Box is then to another group to finish. Each member of the group assigned to analyze and explore the completion of the existing problems. This game process can be performed to assess creativity, responsibility, and student active in class. 


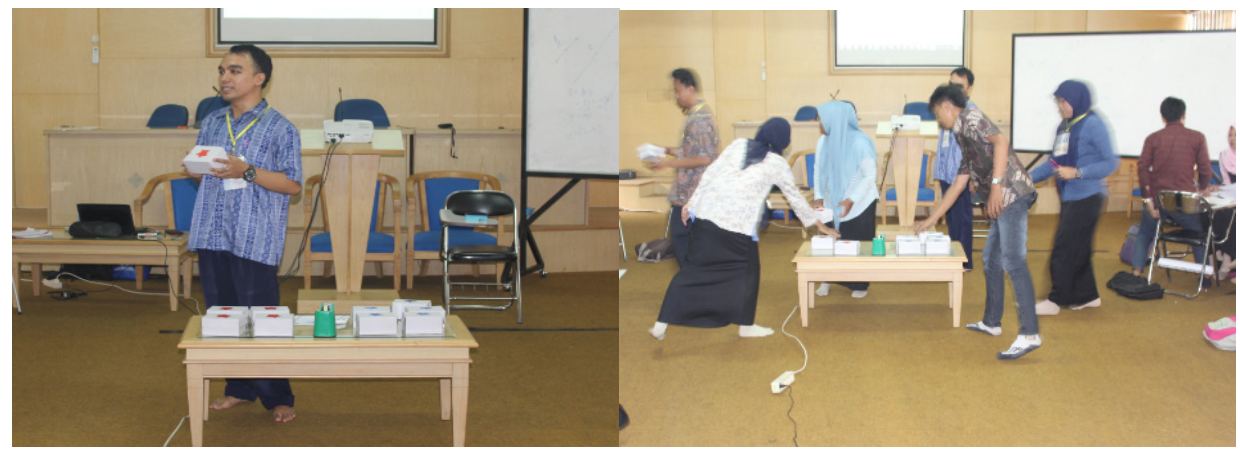

Figure 1. Lecturer provides guidance to students about mystery box

The very first meeting suffered severely from two things. Firstly, due to a college event, the lecturer had found little time to prepare the course and to acquaint himself well enough with the tools and equipment. Secondly, the course class could be made it like the figure below.

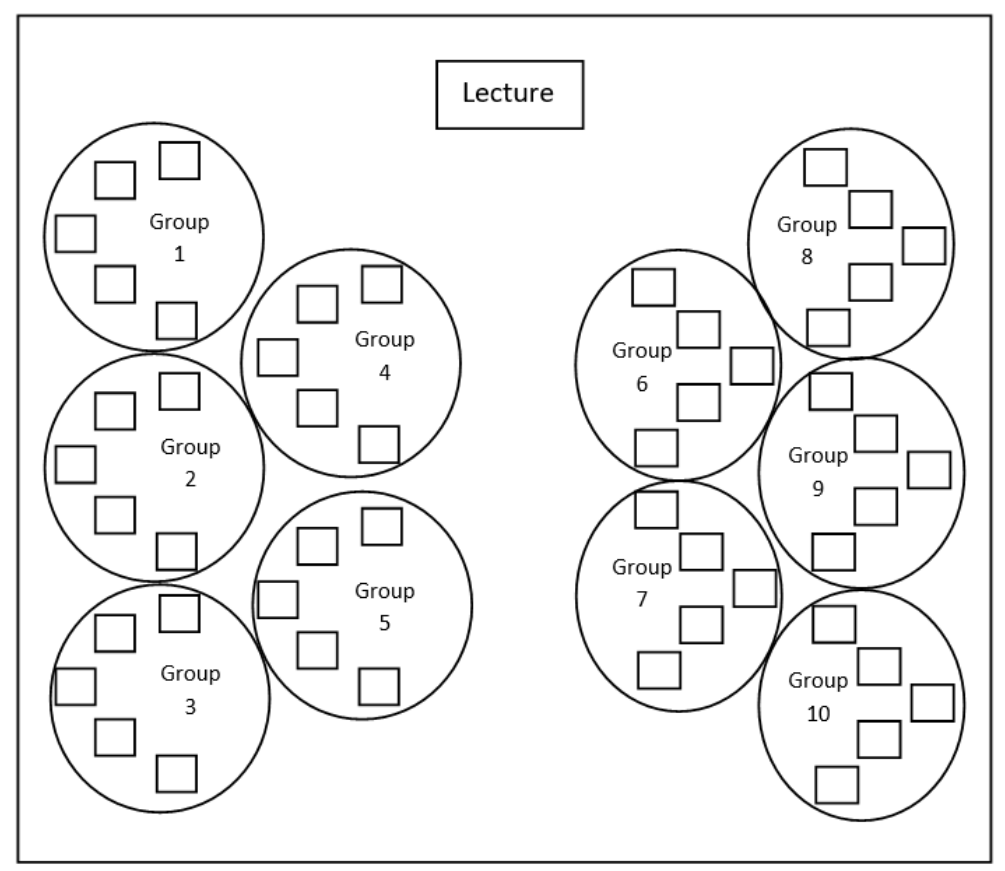

Figure 2. Set up of the classroom. The rectangles represent chairs (one circle was 5 chairs)

the class was only 100 minutes, which was really too short for meeting. Although the student evinced as well as in the upcoming gaming works. Learning in class begins with the division of the group by the lecturer to the students. One group consisted of 5 students, this means that there are 10 groups.

\section{Students activities in Mystery Box}

Make one problem which related by material on learning today and made on the paper.Learningbeginswiththe process offindinga conceptthat is based ongroup discussions. Each groupmustfind aconceptthat isbeing studied. Once theconceptis foundbyeachgrouplearning, lecturersprovide directiontointegrate perceptionandconcept createdbystudents. Once theconceptis embedded, thencreatedaproblemthat is basedon the conceptthatthe issuewas madeina piece of paperthat has been providedbythe lecturer. This stepis thefirststepin themysterybox. 


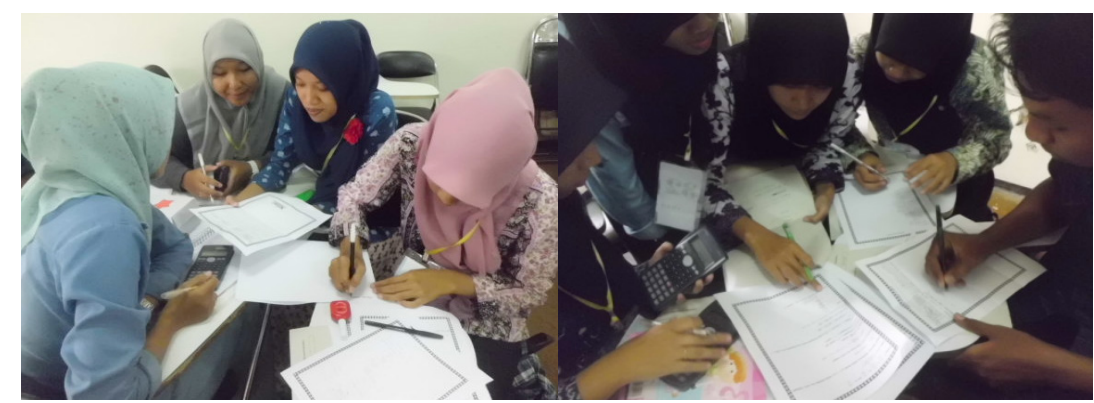

Figure 3. Students discuss with their group about creating one problem and an answer key for it

Make the key answer of the question on a separate sheet of paper about. Problems that have been made by each group, and then made the key answers to these problems. Problems are created and then put in a box and given to another group to be resolved. In the box is already available value that can be obtained. The process of solving problems that exist are given a time limit of 10 minutes.
Each box is available with a different value with the auction system, intheboxare already available value that could be obtained if the groupcansolve the problemsthatexistin thebox. Ifthe groupcan notsolve existing problemsorsettlementis donewrongthen the valuewill bereducedin accordancewithwhatis inthebox.

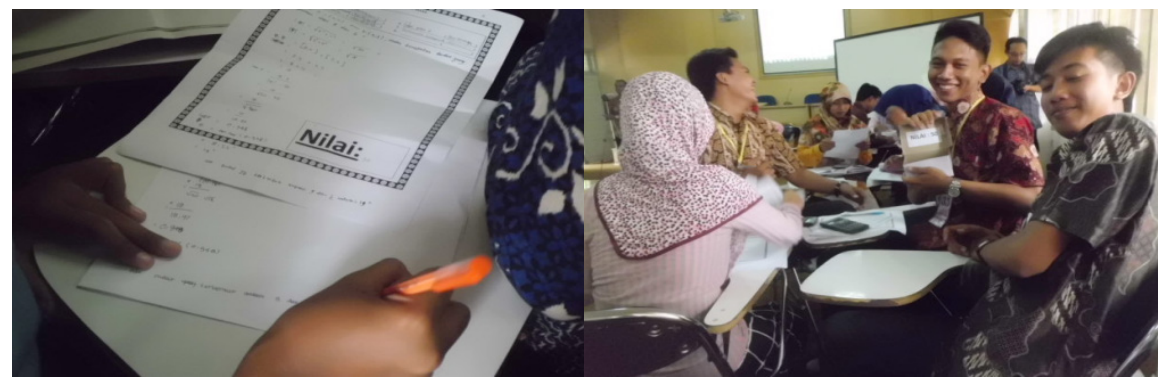

Figure 4. Students do the problems that exist in mystery box

\section{Encouraging Creativity from Mystery} Box Activities

Synthetic ability, is what we typically think of as creativity. It is the ability to generate novel and interesting ideas. Often the person we call creative is a particularly good synthetic thinker who makes connections between things that other people don't recognize spontaneously. The process of looking for a way to solve the problem is done by the discussion in the group, as well as independently process assisted with existing learning resources. These skills indicate that independence in learning and active participation of students in the process of discussion has been able to run well for mathematical ideas such as looking for a long segment for example can be done in several stages and evaluate all of these steps correctly by using the symbol or by using the form graph. How to impress those can be seen from the results of Ilhams work following below. 


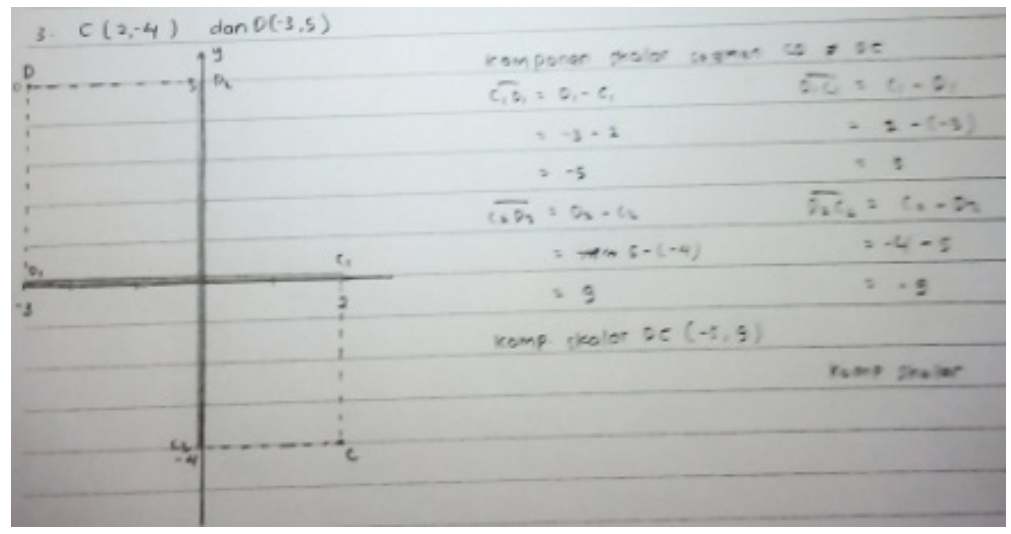

Figure 5. One of synthetic ability that express from Ilham's work

Analytic ability, is typically considered to be critical thinking ability. A person with this skill analyzes and evaluates ideas. Everyone, even the most creative person you know, has better and worse ideas. Without well-developed analytic ability, the creative thinker is as likely to pursue bad ideas as to pursue good ones. The creative individual uses analytic ability to work out the implications of a creative idea and to test it.Almost all students are able to do the task in the classroom and at home with good way. For example Arum can do the job as well as possible, it is seen she can do the job diligently. Doing in class and calculate a segment length by operating the position of two lines. This is illustrate of Arums task how creative she is, belows:
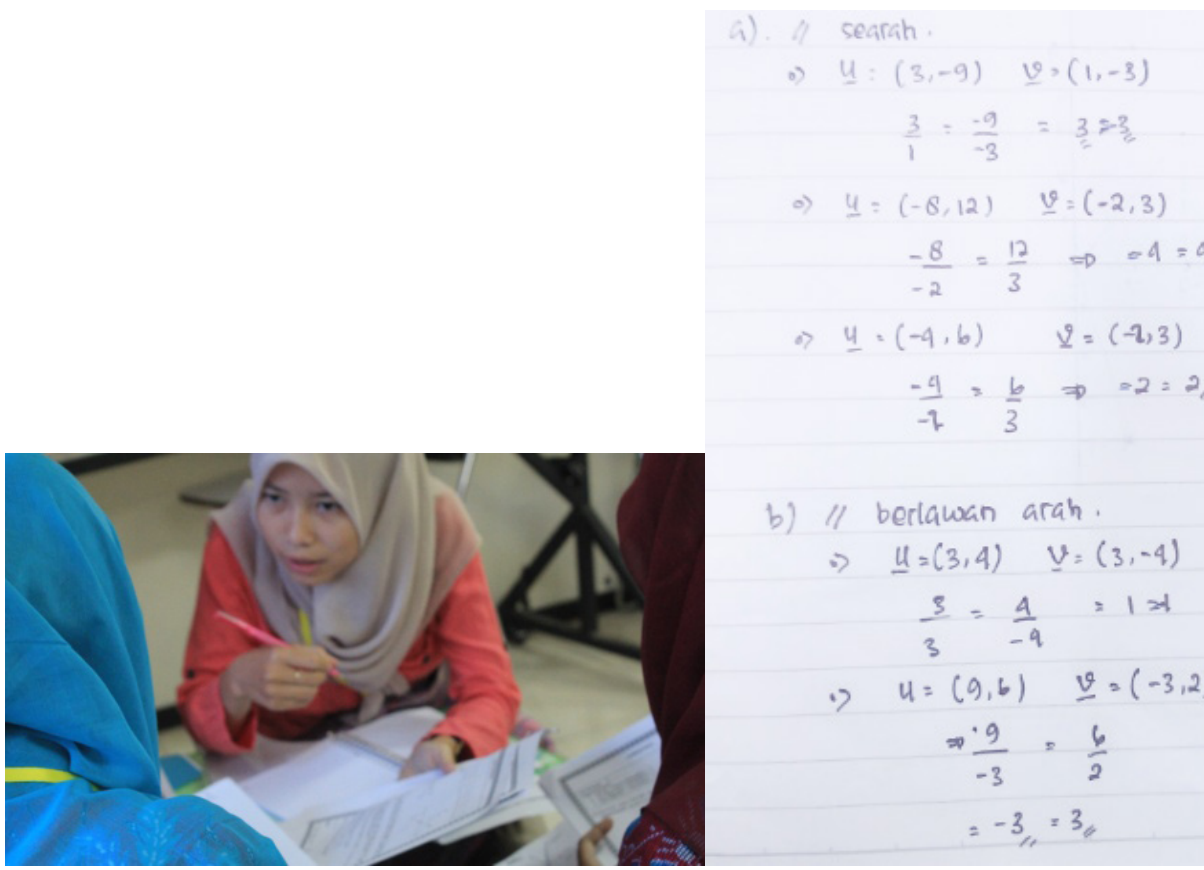

b) 17 berlawan arah

$\Rightarrow \underline{u}=(3,4) \quad \underline{v}=(3,-4)$

$\frac{3}{3}=\frac{4}{-9}=1>1$

.) $u=(9,6) \quad \underline{v}=(-3,2)$

$\Rightarrow \frac{9}{-3}=\frac{6}{2}$

$=-3,=3$,

Figure 6. Students give her ideas with their group and express those ideas in their work

Practical ability, is the ability to translate theory into practice and abstract ideas into practical accomplishments. An implication of the investment theory of creativity is that good ideas do not sell themselves. The creative person uses practical ability to convince other people that an idea is worthy. For example, every organization has a set of ideas that dictate how things, or at least some things, should be done. To propose a new procedure you must sell it by convincing others that it is better than the old one. Practical ability is also used to recognize ideas that have a potential audience.In general, Mystery Box can be 
done by many steps. Students are enthusiastic in solving existing problems and help each other to solve those problems. Students now have started to dare to express their opinions, ideas, or objections to the class, as well as in the group.

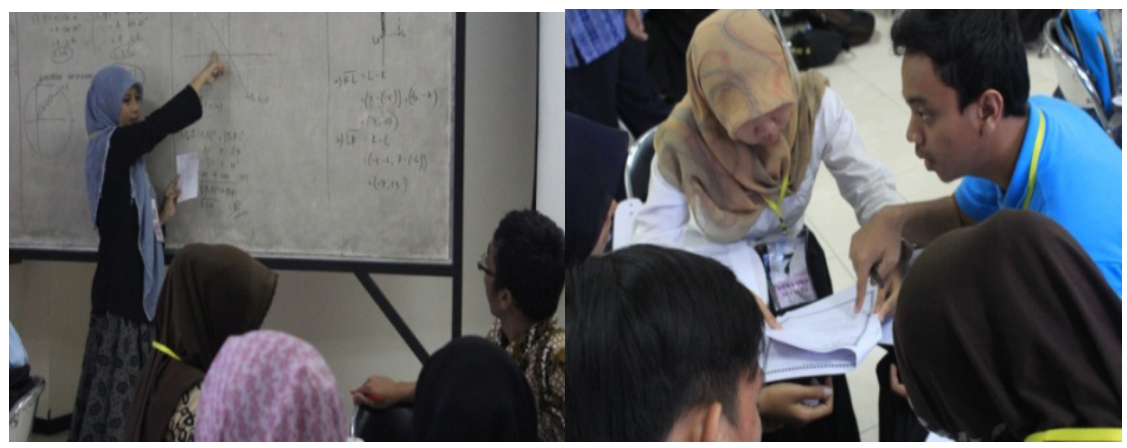

Figure 7. Students practical ability in their group and in front of the class

There is a significant difference between the learning method using the game and without game. The learning method using the game can increase creativity, imagination, and innovation in students. So with interactive educational games, learning can be done effectively and efficiently. Teaching and learning process will run fun and not boring. By contrast, the learning method without using the game. The ability of creativity, imagination, and innovative in students is not so well developed as a method of learning that only focus on theoretical basis alone. So that this kind of learning methods by some students felt quite boring and that is the one reason why students become lazy in learning. Active learning includes use of creative stuffs like games, concepts, maps and study materials. Active learning can only be encouraged when student enjoys the learning environment. Here are some ideas through which lecturers can cultivate creative thought through active learning:

- Create interactions that provide students a lot problem-solving opportunity

- Give them a lot of opportunities for hands-on field work

- Organize round-table discussion time to time on interesting topics

- Permit students to create some of the question for their upcoming exam
One factor that is often considered to be important is to foster the creativity of young students to learn is the subject matter itself and lecturers deliver lessons that (Stenberg \& Lubart, 2009) considering of the various reasons for learning, then learning innovation is essential to apply the learning process. Learning innovation is needed in order to improve the efficiency, relevance, quality and effectiveness. Innovations expected students to be active human, creative and skilled solve their own problems (Singh, 2010).According to (Getzels, 2008) creativity for students is a game. Since infancy, they have developed a wide range of creative play. Therefore, the learning method with the game is the first step towards creativity students. The example one is mystery box. With this game the author wants to deliver and foster student creativity in the classroom and can be maximized to study at home or outside the classroom.

Mystery Box has many advantages. In addition students are not bored in the study, the subject matter becomes younger transmitted from lecturer to student. In addition, interactive educational games are also able to condense the time required to complete acompetency because witht his game the students more quickly capture the lessons that can save time to educate them. The steps are: a)make one problem which 
related by material on learning today, b) problem is made in the paper available, c) make the key answer of the question on a separate sheet of paper about, d) the answer key is made in the other paper, e) time to answer the questions are 10 minutes, $\mathrm{f}$ ) once the matter is made, then put in a box that has been provided, g) each box is available with a different value with the auction system, $h$ ) then the box is opened and do on the problems that exist in it. If the matter is done right, then the value which obtained in accordance with the existing value in each box, i) conversely, if the matter can not be done obtained or done incorrectly, then the group will be reduced in accordance with the value of the value in the box

\section{Conclusion}

This study examined several factors in the educational setting and their relationships to mathematical creativity in search of a simpler means to encourage students' creativity in mathematics. This research is one of the approaches to assess, identify or classify students' creativity. This was the phenomenon the authors hoped to explain when began this study. The findings in this study have provided us with an explanation for what authors experienced.

As a researcher, examining these questions has suggested some answer but has raised many more questions. How applicable is the teaching and learning activity based on a mystery box games in geometry course to encouraging the students creativity? How does the implementation of mystery box games in geometry course in Math Education Students in Muhammadiyah University of Purwokerto? Finally, I hope this research will stimulate others to continue the research, verify, modify, or apply it.

\section{References}

Bobango, T. 1993. Geometry and analytic calculus. New York : Routledge

Baker, Scott and Gersten, Russell. 1998. Teal world use of scientific concepts: integrating situated cognition with explicit instruction. California: Exceptional Students Press

Balka,C. 1974. Affective dimensions of learning. South California: Thomson Wadsworth

De Sonza, F.D. 1998. Development of mathematical communicaton in problem solving groups by language Minority Students. New York : Mc. Graw hill companies

Colburn, Alan. 2000. An Inquiry Geometry. Toronto: Science Scope

Davis, R. 1969. Students's Ideas in Science. United Kingdom: Open Press.

Evan,G. I. 1964. A summary of a study of schooling: Some finding and Hypotheses. Toronto: Phi Delta Kappan

Fleith, Denise de Sonza. 2010. Lecturer and student perceptions of creativity in the classroom environment. New Jersey: Lawrence Erlbaum Associates, Publishers

Getzels,G.,\& Jackson,F.S. 2008. Teaching science with toys and gaming. California: College Teaching Summer Press

Hashimoto. 1997. Opening assessment to our students social education. Alabama: The University of Alabama Press.

Haylock. 2011. Science education. New York: Learning Express

Hennessdy, Beth A. 2008. Teaching for creative development: A social-psychological approach. Needman Heights, MA: Allyn \& Bacon.

Jensen,I. 2009. Character countism. Washington: National Academy Press 
Kohler, L. 1997. How to make hands-on science work for you. New York: Eric Clearinghouse on Information and Technology

Masduki, M., et.al., 2015. Pengembangan karakter dalam pembelajaran mateamtika: model di prodi pendidikan matematika FKIP UMS. Jurnal Varia Pendidikan, 26, 2, pp. 104115. Available: http://journals.ums.ac.id/index.php/varidika/article/view/678

Ross, Michael Elsohn. 2012. Science their way. Young Students, pp 63.

Singh,Y.E. 2010. School science in gaming. London and New York: The Penguin Group

Sloan, Megan. 1996. I love geometry. California: College Express Group

Sheeffield,et.al. 2009. First- and second-grade studetns communication in mathematics. teaching students mathematics. Toronto: Thomson Wadsworth

Stenberg \& Lubart, 2009. Using think time and wait time skillfully in the classroom. Texas: ERIC Digest

Tayman, Juliann M. and Thompson, Kathleen Lewis. 1996. Taking the chaos out of cooperative learning: the 3 most important components. New Jersey: The Clearing House Company in Press

Widjaja, Y.B. 2002. How realistic approach and gaming based lesson work in Indonesian secondary school classroom [On-line]. Unpublished master's thesis, University of Amsterdam, the Netherlands. Available: http://www.science.uva.nl/research/math/ examen/2002/widjaja.pdf.

Wirawati, I. \& Kurniawan, F. 2015. How teacher become "good" at what they do a narrative approach.. Jurnal Varia Pendidikan, 27, 1, pp. 62-69. Available: http://journals.ums. ac.id/index.php/varidika/article/view/740/472 